\title{
Whoso Hath This World's Good. Anthem
}

Author(s): J. Baptiste Calkin

Source: The Musical Times and Singing Class Circular, Vol. 17, No. 395 (Jan. 1, 1876), pp. 335-339

\section{Published by: Musical Times Publications Ltd.}

Stable URL: http://www.jstor.org/stable/3354558

Accessed: 20-06-2016 10:53 UTC

\footnotetext{
Your use of the JSTOR archive indicates your acceptance of the Terms \& Conditions of Use, available at

http://about.jstor.org/terms
}

JSTOR is a not-for-profit service that helps scholars, researchers, and students discover, use, and build upon a wide range of content in a trusted digital archive. We use information technology and tools to increase productivity and facilitate new forms of scholarship. For more information about JSTOR, please contact support@jstor.org.

Musical Times Publications Ltd. is collaborating with JSTOR to digitize, preserve and extend access to The Musical Times and Singing Class Circular 
From the Service in B flat.

\section{ANTHEM.}

J. Baptiste Calkin.

London: NOVELlo, EWER AND CO., 1, Berners Street (W.), and 35, Poultry (E.C.) New York: J. L. PETERS, 843, Broadway.
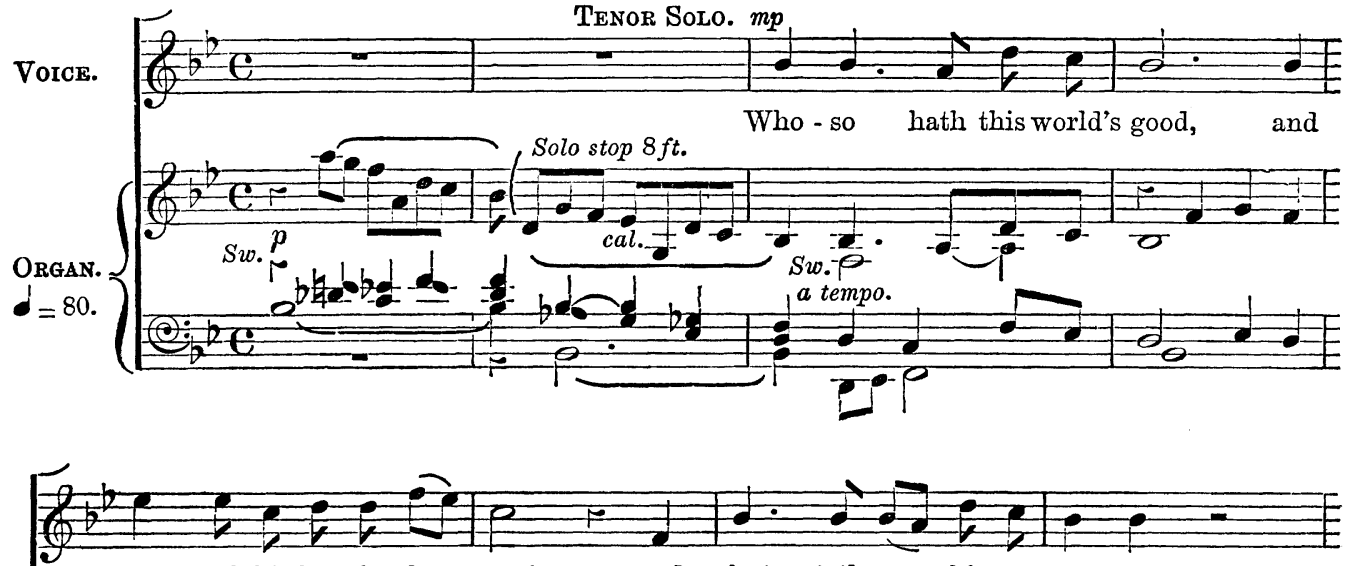

se - eth his bro-ther have need, and shut - teth up his com-pas-sion,
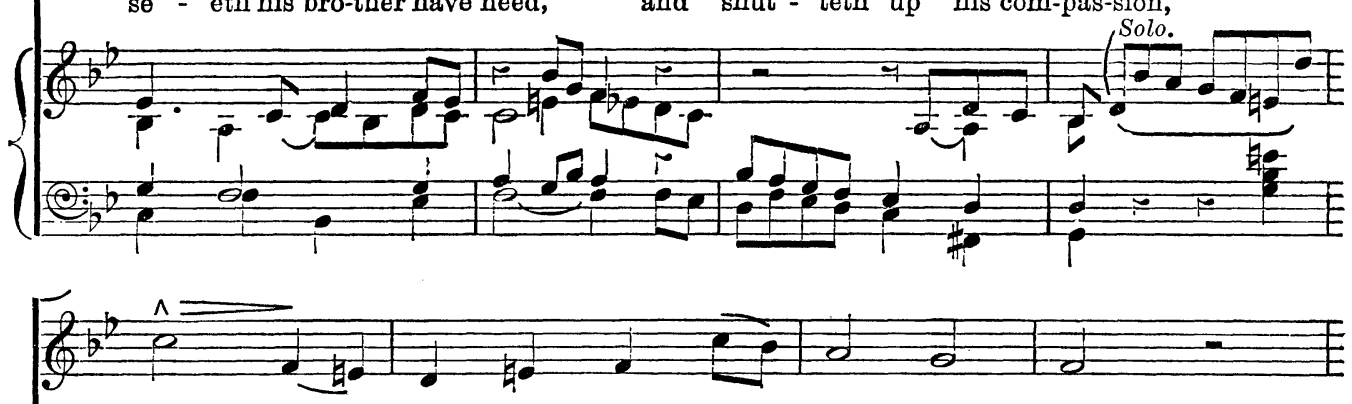

How dwel - leth the love of God in him?

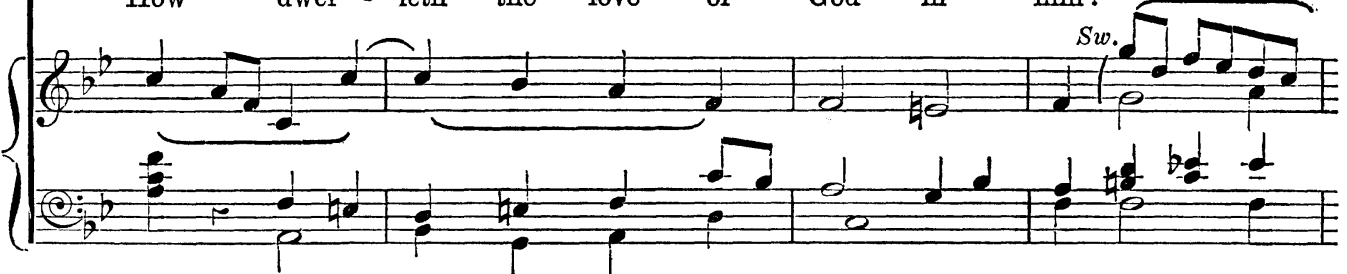

Quartet. Treble. Solo.

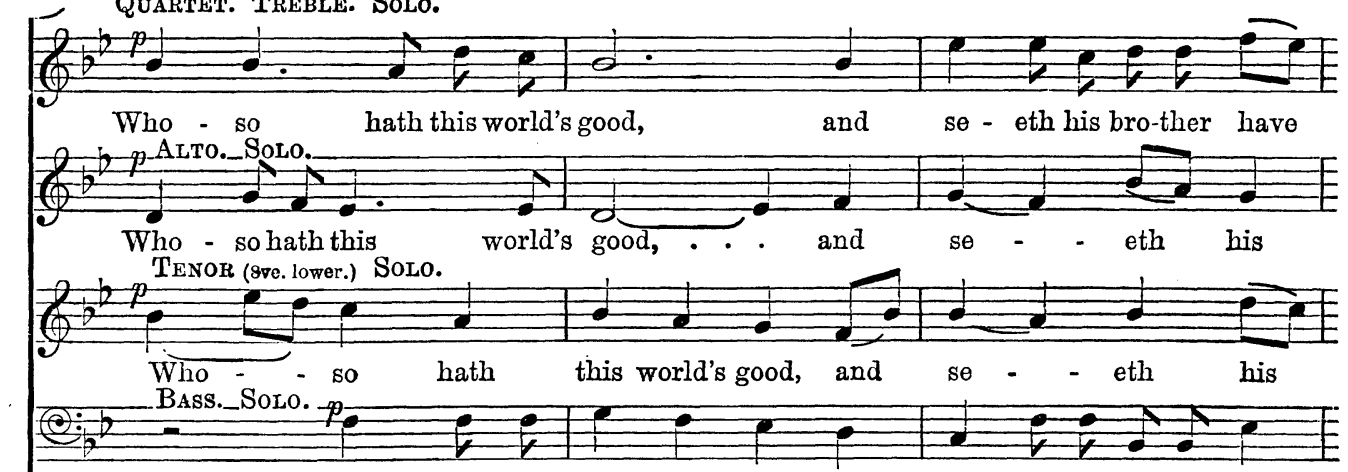

Who - so hath this world's good, and se - eth his bro-ther have

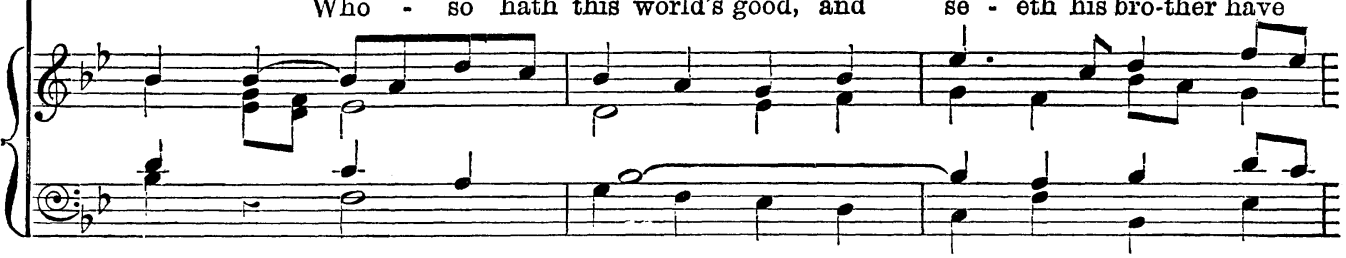

The Musical Times, No. 395.

(1) 

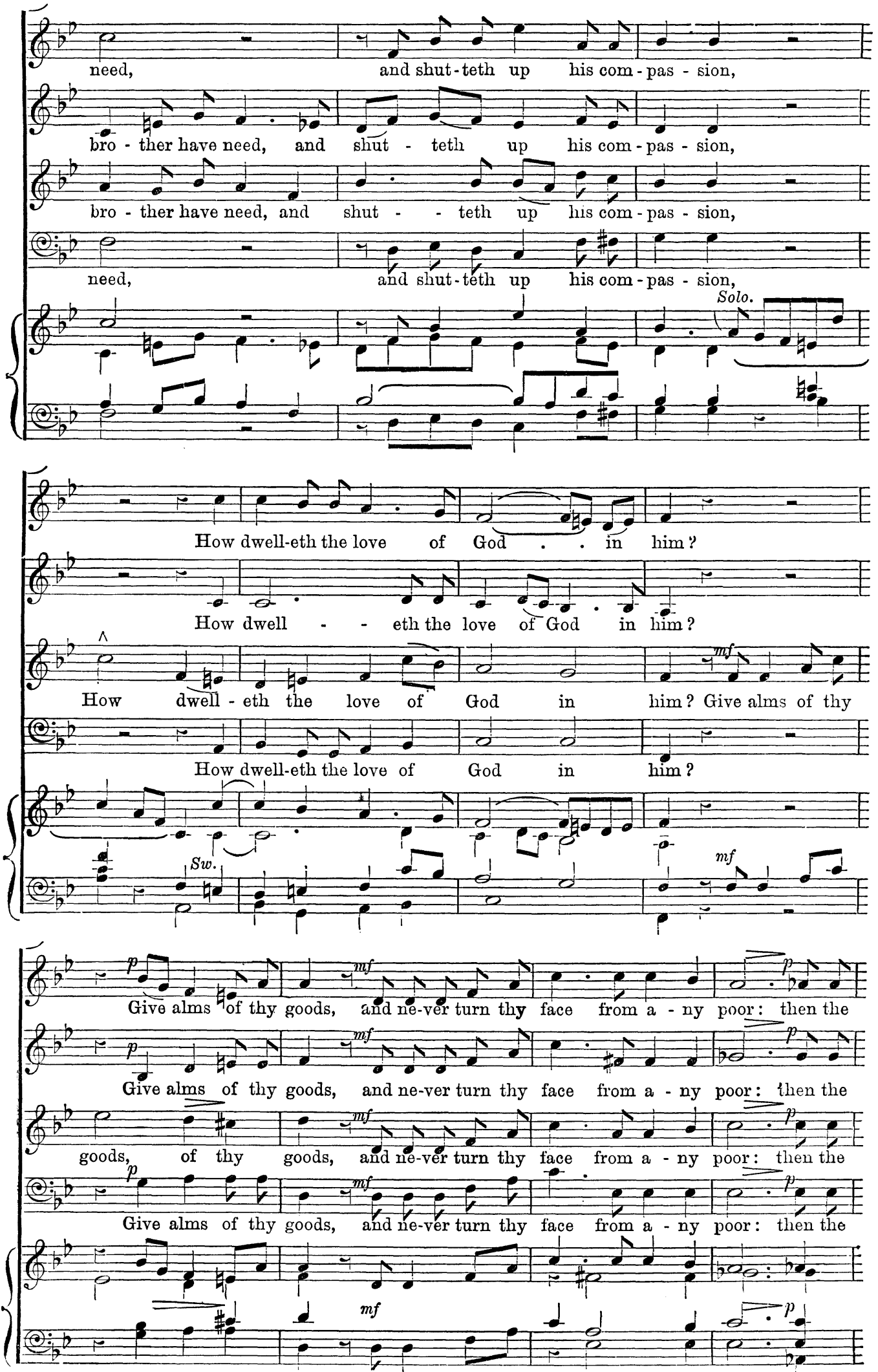

(2) 

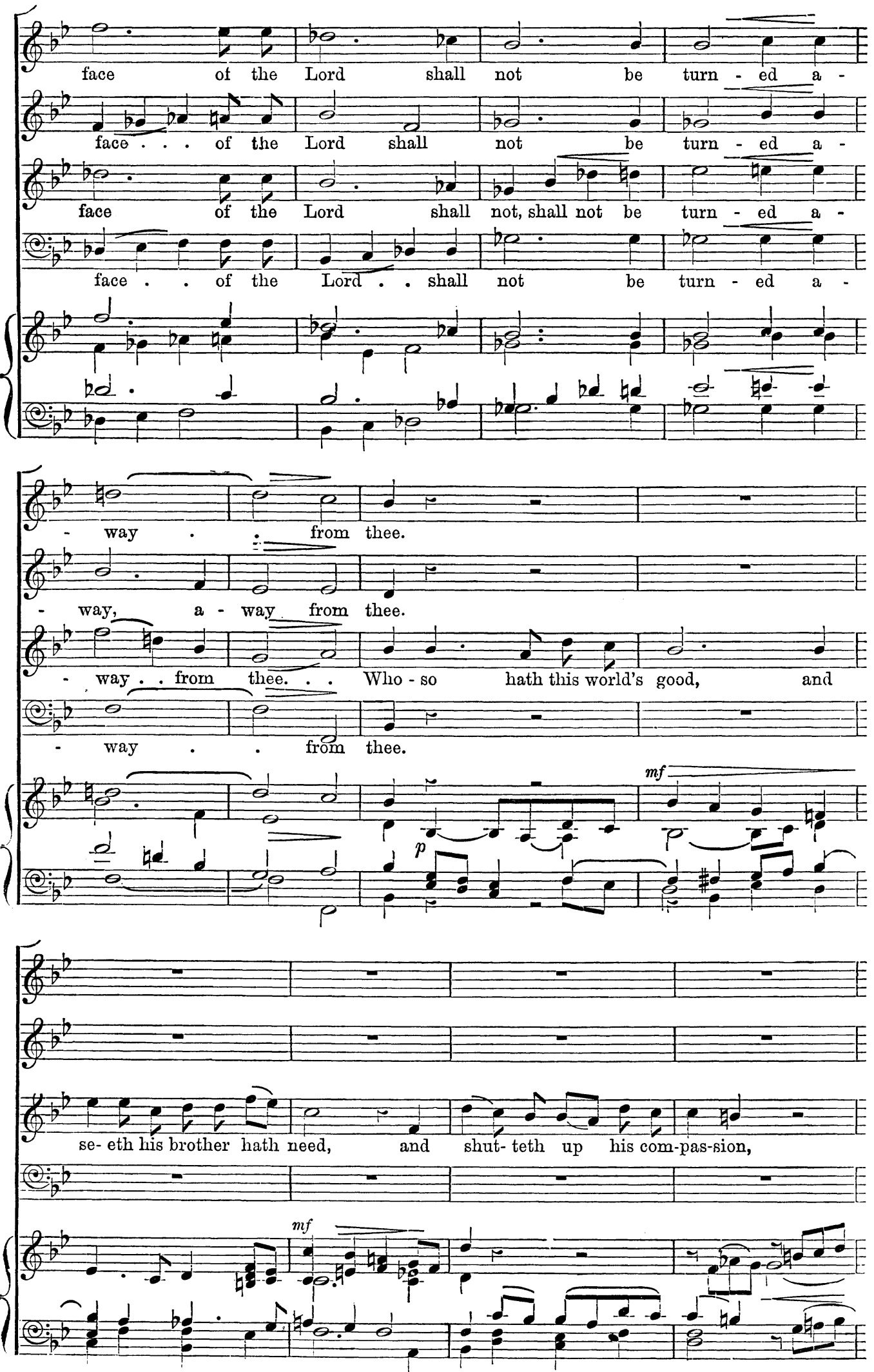

(3) 

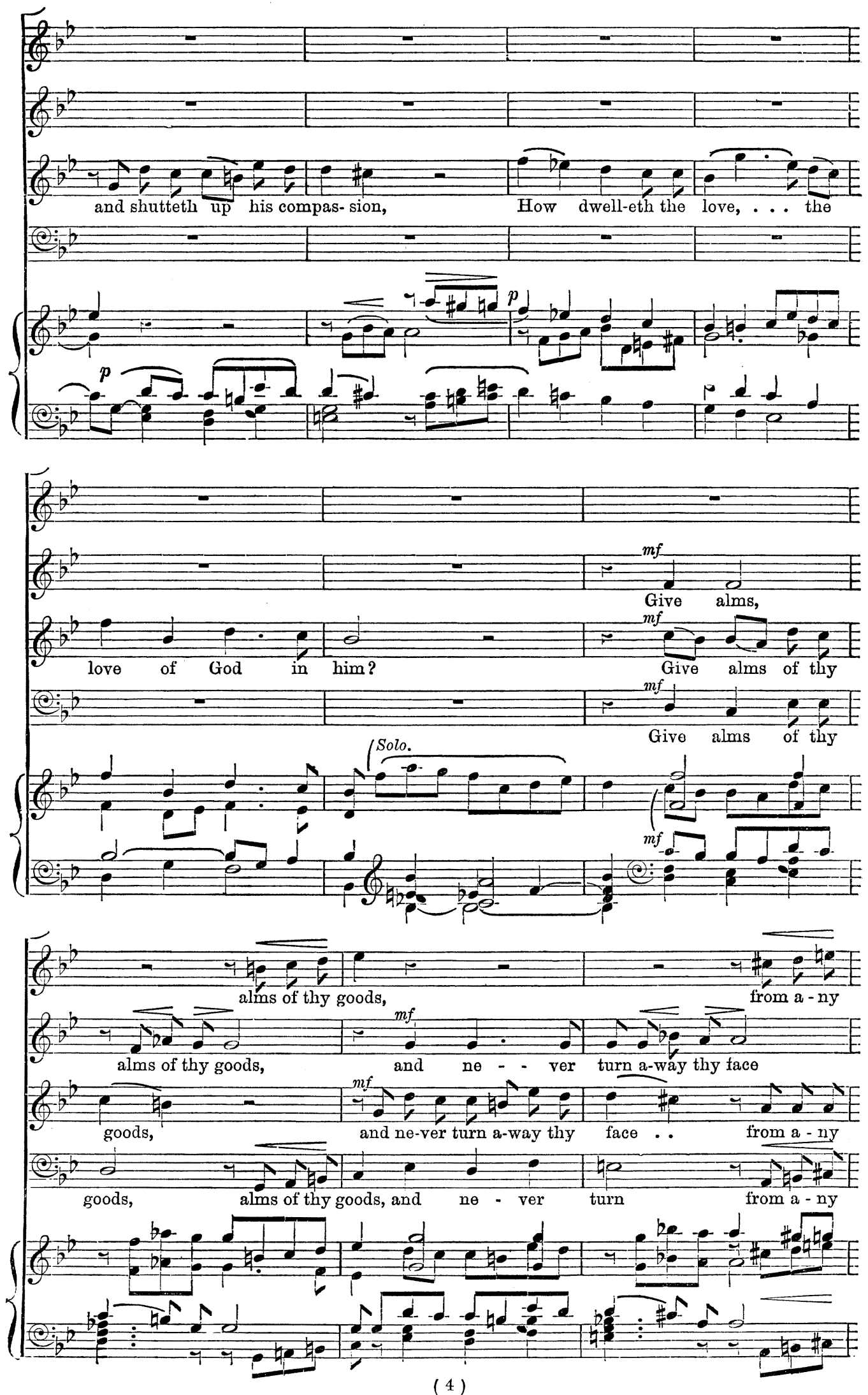

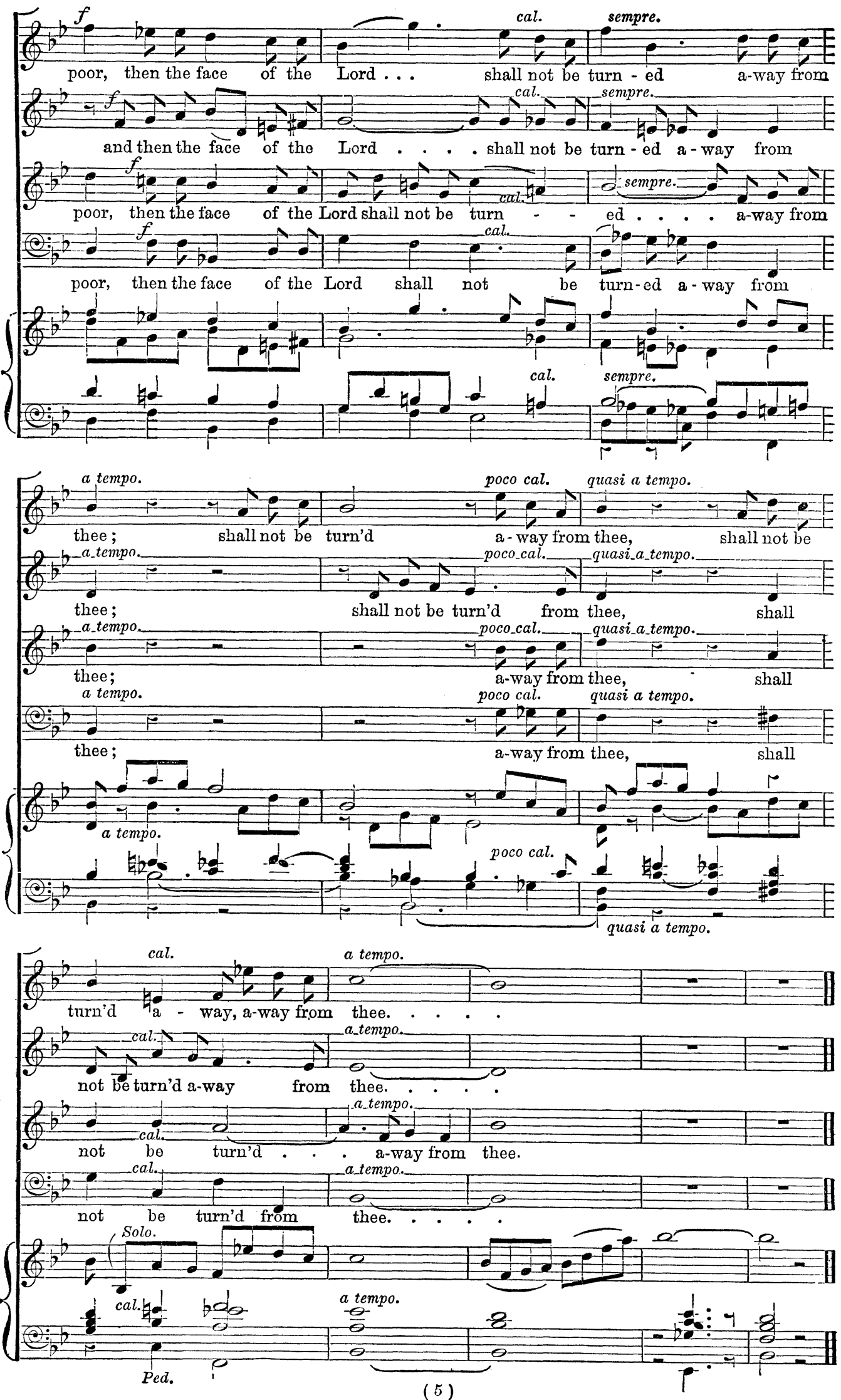